\title{
Between Sollen and Sein: The CJEU's reliance on international law in the interpretation of economic agreements covering occupied territories
}

\author{
Eva Kassoti* \\ TMC Asser Institute, R.J. Schimmelpennincklaan 20-22, 2517 JN Den Haag, Netherlands \\ Email: E.Kassoti@asser.nl
}

\begin{abstract}
This contribution focuses on the Court of Justice of the European Union (Court or CJEU) reliance on international law in cases involving economic agreements covering occupied territories. In its earlier case law, the Court adopted a formalistic approach by ignoring the broader international legal framework of the dispute in an effort to achieve conformity with international law, while at the same time avoiding being drawn into political storms. The article continues by identifying an even more worrisome trend in the Court's latest judgments in the Front Polisario and Western Sahara Campaign UK cases. In these two cases the Court showed its willingness to stretch the international rules of treaty interpretation to a breaking point in order to avoid pronouncing on the politically sensitive question of the de facto application of the EU's agreements with Morocco in the territory of Western Sahara. The article concludes by asserting that the Court's line of argumentation brings another dimension to the Völkerrechtsfreundlichkeit debate. The classical, binary understanding of the Court's approach as 'open/hostile' to international law only provides us with a partial picture of how international law was actually used in these cases. The Court's apparent willingness to rely on international law as a heuristic device to reinforce an outcome that radically departs from the logic and structure of international law and international legal argumentation requires a more in-depth engagement with both the content of the international law rules invoked in those judgments and with the Court's use of such rules.
\end{abstract}

Keywords: CJEU; non-recognition; occupied territories; self-determination; treaty interpretation

\section{Introduction}

The CJEU's judgment in the Western Sahara Campaign UK case $^{1}$ is the latest in a series of judgments, spanning over two decades, pertaining to different aspects of the EU's economic agreements extending to occupied territories. This line of case law is important in the context of the ever-growing debate regarding the CJEU's approach to international law; it has been argued in the literature that, although in its earlier case law the Court seemed to have adopted a friendly and open attitude towards international law, more recent case law evidences a more reserved, inward-looking attitude and a tendency to eschew engagement therewith. ${ }^{2}$ Revisiting the

${ }^{\star}$ Ph.D., Senior Researcher in International and EU Law T.M.C. Asser Institute, Academic Co-Ordinator of the Centre for the Law of EU External Relations (CLEER).

${ }^{1}$ Case C-266/16, Western Sahara Campaign UK v. Commissioners for Her Majesty's Revenue and Customs, Secretary of State for Environment, Food and Rural Affairs, [2018] EU:C:2018:118.

${ }^{2}$ For an overview see generally C. Eckes, 'International Law as Law of the EU: The Role of the ECJ', in E. Cannizzaro, P. Palchetti and R. Wessel (eds.), International Law as Law of the European Union (2011), 353.

(c) The Author(s) 2020. This is an Open Access article, distributed under the terms of the Creative Commons Attribution licence (http:// creativecommons.org/licenses/by/4.0/), which permits unrestricted re-use, distribution, and reproduction in any medium, provided the original work is properly cited. 
CJEU's Völkerrechtsfreundlichkeit debate from this vantage point is highly relevant since these cases invariably involve questions of interpretation and application of cardinal principles of international law, such as the duty of non-recognition, the principle of self-determination and the right to permanent sovereignty over natural resources. In this light, this contribution focuses on the Court's reliance on international law in cases involving economic agreements covering occupied territories.

The article argues that the Court's approach to international law in these cases is highly problematic. In its earlier case law, including Anastasiou ${ }^{3}$ and Brita, ${ }^{4}$ the Court adopted a formalistic and one-dimensional approach by ignoring the broader international legal framework of the dispute in an effort to achieve conformity with international law, while at the same time avoiding being drawn into political storms. The article continues by identifying an even more worrisome trend in the Court's latest judgments in the Front Polisario ${ }^{5}$ and Western Sahara Campaign UK cases. In these two cases the Court, instead of simply ignoring relevant international law norms, showed its willingness to stretch the international rules of treaty interpretation to a breaking point in order to avoid pronouncing on the politically sensitive question of the de facto application of the EU's agreements with Morocco in the territory of Western Sahara.

The article concludes by asserting that the Court's line of argumentation in its more recent case law pertaining to economic agreements covering occupied territories brings another dimension to the Völkerrechtsfreundlichkeit debate. The classical, binary understanding of the Court's approach as 'open/hostile' to international law only provides us with a partial picture of how international law was actually used in these cases. The Court's apparent willingness to rely on international law as a heuristic device to reinforce an outcome that radically departs from the logic and structure of international law and international legal argumentation requires a more in-depth engagement with both the content of the international law rules invoked in those judgments and with the Court's use of such rules.

\section{Earlier jurisprudence of the CJEU relating to economic agreements covering occupied territories: The Anastasiou and Brita cases}

The two most important judgments involving economic agreements extending to occupied territories prior to the Western Sahara litigation before the CJEU were Anastasiou and Brita. Arguably, in both cases, the Court ignored the broader international legal framework of the dispute (including the legal status of the territories in question as 'occupied' ones as well as the concomitant obligation of non-recognition on behalf of the EU) in an effort to ensure respect to international law, while, at the same time, avoiding politically contentious issues.

The Anastasiou case arose from an action brought by a number of Greek Cypriot producers before the UK High Court of Justice for judicial review of the practice of UK authorities of accepting origin certificates (pursuant to the 1977 Protocol regarding products originating from Cyprus) ${ }^{6}$ and phytosanitary certificates (pursuant to Directive 77/93/EEC on protective measures against the introduction into the Community of organisms harmful to plants or plant products) ${ }^{7}$ issued by the authorities of the self-proclaimed Turkish Republic of Northern Cyprus (TRNC). ${ }^{8}$ The Court stated that the

\footnotetext{
${ }^{3}$ Case C-432/92, The Queen v. Minister of Agriculture, Fisheries and Food, ex parte Anastasiou, [1994] ECR I-3087.

${ }^{4}$ Case C-386/08, Firma Brita GmbH v. Hauptzollamt Hamburg-Hafen, [2010] ECR I-1289.

${ }^{5}$ Case C-104/16 P, Council of the European Union v. Front populaire pour la libération de la saguia-el-hamra et du rio de oro (Front Polisario), [2016] ECLI:EU:C:2016:973.

${ }^{6}$ Council Regulation 290/77 of 20 December 1977 on the conclusion of the Additional Protocol to the Agreement establishing an Association between the European Economic Community and the Republic of Cyprus, OJ [1977] L339/1.

${ }^{7}$ Council Directive 77/93/EEC of 21 December 1976 on protective measures against the introduction into the Community of organisms harmful to plants or plant products, OJ [1977] L26/20.

${ }^{8} \mathrm{~S}$. Talmon, 'The Cyprus Question before the European Court of Justice', (2001) 12 EJIL 727, at 734-7.
} 
non-recognition of the TRNC either by the EU, or by its member states, precluded the possibility of mutual reliance and co-operation between the entity's authorities and those of the member states according to the 1977 Protocol. ${ }^{9}$ On this basis, it was held that 'the acceptance of movement certificates not issued by the Republic of Cyprus would constitute ... a denial of the very object and purpose of the system established by the 1977 Protocol'. ${ }^{10}$

In Anastasiou, the Court's reasoning was not based on international law; the judgment evidences no engagement with the question of Community's obligation of non-recognition ${ }^{11}$ of the acts of the occupying authorities under international law. More particularly, the Court did not address at all the argument put forward by the Greek Government to the effect that acceptance of the certificates issued by the Turkish authorities in Northern Cyprus would be tantamount to violating a number of UN Security Council Resolutions ${ }^{12}$ condemning the Turkish occupation and calling upon all members of the international community not to recognize the self-proclaimed TRNC. ${ }^{13}$ Although the Court did acknowledge the de facto partition of the island, the problems stemming from this situation were merely regarded as pertaining to the 'internal affairs of Cyprus' which should be resolved 'exclusively by the Republic of Cyprus, which alone is internationally recognized'. ${ }^{14}$

On the contrary, the Court framed its analysis in terms of the need to maintain the uniform application of Community rules in its trade relations. ${ }^{15}$ The CJEU underscored that a strict interpretation of the 1977 Protocol was required in order to ensure uniform application of the [EU-Cyprus] Association Agreement in all the Member States'. ${ }^{16}$ According to Koutrakos, this approach shows that the Court seeks to ensure the uniformity and effectiveness of EU law 'whilst intervening as little as possible in an issue which is highly charged in political terms' and is fully consistent with 'the case-law in other areas of trade policy with significant foreign policy overtones, namely economic sanctions against third countries and exports of dual-use goods'. ${ }^{17}$

In Brita, the CJEU was confronted with the question of the territorial scope of the EU-Israel Association Agreement. ${ }^{18}$ The case concerned the import to Germany of goods from an Israeli company located in the West Bank. ${ }^{19}$ The German authorities withdrew the benefit of preferential treatment on the ground that it could not be conclusively established that the imported goods fell within the scope of the EU-Israel Association Agreement. ${ }^{20}$ Brita, the company that imports the products in question, brought the issue before the German courts, which then submitted a preliminary question to the CJEU. ${ }^{21}$

Despite an express invitation by the Advocate General to analyse the legal status of Israel's presence in the West Bank for the purpose of establishing the territorial scope of the Association

\footnotetext{
${ }^{9}$ Anastasiou, supra note 3, paras. $39-40$.

${ }^{10}$ Ibid., para. 41.

${ }^{11}$ On the duty of non-recognition under international law, see Legal Consequences for States of the Continued Presence of South Africa in Namibia (South West Africa) notwithstanding Security Council Resolution 276 (1970), Advisory Opinion of 21 June 1971, [1971] ICJ Rep. 16, paras. 122, 124. Legal Consequences of the Construction of a Wall in the Occupied Palestinian Territory, Advisory Opinion of 9 July 2004, [2004] ICJ Rep. 136, para. 159.

${ }^{12}$ UN Doc. S/RES/541 (1983).

${ }^{13}$ P. Koutrakos, 'Legal Issues of EC-Cyprus Trade Relations', (2003) 52 ICLQ 489, at 492. N. Skoutaris, The Cyprus Issue: The Four Freedoms in a Member State under Siege (2011), 130.

${ }^{14}$ Anastasiou, supra note 3, para. 47.

${ }^{15}$ N. Emiliou, 'Cypriot Import Certificates; some hot potatoes', (1995) 1 European Law Review 202, at 209.

${ }^{16}$ Anastasiou, supra note 3, para. 54.

${ }^{17}$ Koutrakos, supra note 13 , at 493.

${ }^{18}$ Euro-Mediterranean Agreement establishing an association between the European Communities and their member states, of the one part, and the State of Israel, of the other part, adopted on 20 November 1995, entered into force 01 June 2000, OJ [2000] L147/3. (EU-Israel Association Agreement).

${ }^{19}$ Brita, supra note 4 , para. 30 .

${ }^{20}$ Ibid., para. 33.

${ }^{21}$ Ibid., paras. $35-6$.
} 
Agreement, ${ }^{22}$ the Court decided the matter solely with reference to the 'politically-detached' principle of pacta tertiis. ${ }^{23}$ The CJEU argued that the EU-PLO Association Agreement ${ }^{24}$ implicitly restricted the territorial scope of the EU-Israel Association Agreement. ${ }^{25}$ The failure to take into account the broader international legal framework of the dispute (including the status of Israel as an occupying power; the violation of the Palestinian peoples' right to self-determination; and the concomitant obligation of non-recognition on the part of the EU) in interpreting the territorial scope of the EU-Israel Association Agreement leaves much to be desired. ${ }^{26}$ In this light, it is difficult to escape the conclusion that, by not relying more heavily on international law, the Court sought to achieve conformity with EU law while avoiding being drawn into contentious political issues. ${ }^{27}$ However, this judicial strategy severely undermines the normative power of European narrative and lends evidentiary force to the argument that the CJEU, in its practice, shows a great deal of 'judicial recalcitrance' towards international law. ${ }^{28}$

\section{The Western Sahara cases before the CJEU: Factual and legal background to the Western Sahara dispute}

Against this backdrop, the remainder of the article zooms in on the Western Sahara litigation before the CJEU - a line of case law that is of particular significance since it involves questions of interpretation of economic agreements covering an occupied territory. Before embarking on an analysis of the relevant judgments, this section sketches out the factual and legal background of the Western Sahara dispute.

In 1963, the UN added Western Sahara, formerly a Spanish colony, ${ }^{29}$ to its list of non-selfgoverning territories. ${ }^{30}$ Three years later, the UN General Assembly urged Spain, as the administering power, to hold a referendum in order to enable the indigenous peoples of the territory to 'exercise freely [their] right to self-determination' ${ }^{31}$ Front Polisario was formed in 1973 with a view to gaining independence for Western Sahara. ${ }^{32}$ Competing claims between Morocco and Mauritania over the territory prompted the UN General Assembly to request an advisory opinion from the ICJ. ${ }^{33}$ The Court opined that no legal ties existed between Western Sahara and Morocco and Mauritania of such a nature that could affect the application of the principle of self-determination of the peoples of the territory. ${ }^{34} \mathrm{~A}$ few days after the ICJ rendered its opinion Moroccan armed forces

\footnotetext{
${ }^{22}$ Opinion of Advocate General Bot, Case C-386/08, Firma Brita GmbH v. Hauptzollamt Hamburg-Hafen, supra note 4, paras. 109-12.

${ }^{23}$ G. Harpaz and E. Rubinson, 'The Interface between Trade, Law and Politics and the Erosion of Normative Power Europe: Comment on Brita', (2010) 35 European Law Review 551, at 566.

${ }^{24}$ Euro-Mediterranean Interim Association Agreement on trade and cooperation between the European Community, of the one part, and the Palestine Liberation Organization (PLO) for the benefit of the Palestinian Authority of the West Bank and the Gaza Strip, of the other part, adopted on 24 February 1997, entered into force 1 July 1997, OJ [1997] L187/3. (EU-PLO Association Agreement).

${ }^{25}$ Brita, supra note 4 , paras. $50-3$.

${ }^{26}$ R. Holdgaard and O. Spiermann, 'Case C-386/08, Brita GmbH v Hauptzollamt Hamburg-Hafen, Judgment of the Court of Justice (Fourth Chamber) of 25 February 2010, nyr', (2011) 48 Common Market Law Review 1667, at 1680-2.

${ }^{27}$ Harpaz and Rubinson, supra note 23, at 566.

${ }^{28} \mathrm{~F}$. Casolari, 'Giving Indirect Effect to International Law within the EU Legal Order: The Doctrine of Consistent Interpretation', in Cannizzaro, Palchetti and Wessel, supra note 2, at 395.

${ }^{29}$ See generally T. Franck, 'The Stealing of the Sahara', (1976) 70 AJIL 694.

${ }^{30}$ On Western Sahara's inclusion in the list of non-self-governing-territories, see Letter dated 29 January 2002 from the Under-Secretary-General for Legal Affairs, the Legal Counsel, Hans Corell, addressed to the President of the Security Council, UN Doc. S/2002/161 (2002), para. 5.

${ }^{31}$ UN Doc. A/RES/2229/ XXI (1966).

${ }^{32}$ The UN has recognized Polisario Front as the representative of the people of Western Sahara since 1979. See UN Doc. A/RES/34/37 (1979), para. 7.

${ }^{33}$ Western Sahara, Advisory Opinion of 16 October 1975, [1975] ICJ Rep. 12.

${ }^{34}$ Ibid., para. 162.
} 
entered the disputed territory and soon thereafter an armed conflict broke out between Front Polisario on the one hand, and Morocco and Mauritania on the other. ${ }^{35}$ In February 1976 Spain officially declared its withdrawal from Western Sahara. ${ }^{36}$ Three years later, in 1979, Mauritania and Front Polisario signed a peace agreement under which Mauritania agreed to withdraw its armed forces and relinquished its claim over Western Sahara. ${ }^{37}$ Upon Mauritania's withdrawal, Moroccan armed forces annexed the remainder of the territory. The UN General Assembly swiftly condemned the annexation and characterized the presence of the Moroccan army in the territory as 'occupation'. ${ }^{38}$ Since then, several UN-brokered efforts have been made to resolve the dispute which have, however, proved thus far futile. ${ }^{39}$ As a result, the UN still recognizes Spain as the de jure administering power of Western Sahara, which remains on the UN's list of non-self-governing territories. ${ }^{40}$ A series of resolutions by the UN Security Council and General Assembly have repeatedly affirmed the right of Sahrawi people to self-determination. ${ }^{41}$

From an international legal perspective, there is little doubt that Western Sahara is not only a non-self-governing, but also an occupied territory since Morocco's presence therein meets the objective threshold of occupation under international humanitarian law, namely demonstration of effective authority and control over a territory to which the occupying state holds no sovereign title. ${ }^{42}$ The UN General Assembly has twice characterized the presence of Morocco in Western Sahara as 'belligerent occupation' ${ }^{43}$ and a number of EU member states describe Western Sahara as 'occupied'. ${ }^{4}$ The African Union also considers Western Sahara to be under occupation by Morocco. ${ }^{45}$ It needs to be noted that both the South African court ${ }^{46}$ and the referring court in the Western Sahara Campaign UK case ${ }^{47}$ also subscribe to the same view.

\footnotetext{
${ }^{35}$ www.hrw.org/reports/1995/Wsahara.htm.

${ }^{36}$ Letter dated 26 February 1976 from the Permanent Representative of Spain to the United Nations addressed to the Secretary-General, UN Doc. A/31/56 - S/11997 (1976).

${ }^{37}$ Mauritano-Saharoui Agreement, concluded on 10/08/1979, annexed to Letter dated 18 August 1979 from the Permanent Representative of Mauritania to the United Nations addressed to the Secretary-General, UN Doc. A/34/427 - S/13503 (1979).

${ }^{38}$ UN Doc. A/RES/34/37 (1979), para. 5. See also UN Doc. A/RES/35/19 (1990), para. 3.

${ }^{39}$ For an overview see M. Dawidowicz, 'Trading Fish or Human Rights in Western Sahara? Self-Determination, NonRecognition and the EC-Morocco Fisheries Agreement', in D. French (ed.), Statehood and Self-Determination: Reconciling Tradition and Modernity in International Law (2013), 250, at 260-1.

${ }^{40}$ Information from Non-Self-Governing-Territories transmitted under Article $73 e$ of the Charter of the United Nations, Report of the Secretary General, 03/02/2017, UN Doc. A/72/62 (2017).

${ }^{41}$ For the most recent, see UN Doc. S/RES/2351 (2017); UN Doc. A/RES/71/106 (2016).

${ }^{42}$ See Art. 42 of 1907 Convention (IV) respecting the Laws and Customs of War on Land and its annex: Regulations concerning the Laws and Customs of War (The Hague Regulations), available at ihl-databases.icrc.org/ihl/WebART/195-200052? OpenDocument. 'Territory is considered occupied when it is actually placed under the authority of the hostile army. The occupation extends only to the territory where such authority has been established and can be exercised.' See also C. Chinkin, 'Laws of Occupation', Conference on Multilateralism and International Law with Western Sahara as a case study hosted by the South African Department of Foreign Affairs and the University of Pretoria, 4-5 December 2008, at 198, available at removethewall.org/wp-content/uploads/2014/05/Laws-of-Occupation-Christine-Chinkin-2009.pdf. E. Benvenisti, The International Law of Occupation (2012), at 43.

${ }^{43}$ UN Doc. A/RES/34/37 (1979), para. 5; UN Doc. A/RES/35/19 (1980), para. 3.

${ }^{44}$ See the statements cited in E. Kontorovich, 'Economic Dealings with Occupied Territories', (2015) 53 Columbia Journal Transnational Law 584, at 612, footnote 147.

${ }^{45}$ African Union, Legal Opinion on the legality in the context of international law, including the relevant United Nations resolutions and organization of African Unity/African Union decisions, of actions allegedly taken by the Moroccan authorities or any other State, group of States, foreign companies or any other entity in the exploration and/or exploitation of renewable and non-renewable natural resources or any other economic activity in Western Sahara, Annex to the letter dated 9 October 2015 from the Permanent representative of Zimbabwe to the United Nations addressed to the President of the Security Council, UN Doc. S/2015/786 (2015), para. 21.

${ }^{46}$ South Africa, Eastern Cape High Court, Port Elizabeth, Saharawi Arab Democratic Republic and Another v. Owner and Charterers of the MV 'Cherry Blossom' and Others, [2017] ZAECPEH 31, 15 June 2017, para. 38, available at www.saflii.org/za/ cases/ZAECPEHC/2017/31.html.

${ }^{47}$ Opinion of Advocate General Wathelet, Case C-266/16, Western Sahara Campaign UK v. Commissioners for Her Majesty's Revenue and Customs, Secretary of State for Environment, Food and Rural Affairs, [2018] EU:C:2018:1, para. 246.
} 
However, Morocco denies its status as an occupying power. Rather, it considers the territory 'as an integral part of the Kingdom of Morocco'48 and even refers thereto in the official UN documentation as 'Moroccan Sahara'. ${ }^{49}$ In his 2014 speech to the Nation, King Mohammed VI stated that: "We say "No" to the attempt to change the nature of this regional conflict and to present it as a decolonization issue. Morocco is in its Sahara and never was an occupying power or an administrative power. In fact, it exercises its sovereignty over its territory' and added that 'Morocco's sovereignty over its entire territory is effective, inalienable, and nonnegotiable. ${ }^{50}$ It is important to note that these claims to territorial sovereignty do not affect the legal status of Morocco as an occupying power since, under international humanitarian law, occupation is a matter of fact resting upon the assertion of effective control and authority over a territory. ${ }^{51}$

Before embarking upon the analysis, a brief overview of the EU's approach towards Western Sahara needs to be provided at this juncture in order to clarify the political context within which the CJEU was called to pronounce on the legality of the de facto application of the EU's trade agreements with Morocco to Western Sahara. Although the EU has, on various occasions, expressed concern about the pro-longed nature of the conflict and its implications for security, respect for human rights and co-operation in the region, ${ }^{52}$ it has been observed that its language is 'rather muted'. ${ }^{53}$ The EU Annual Report on Human Rights and Democracy in the World 2014 states that Western Sahara is a 'territory contested by Morocco and the Polisario Front ${ }^{54}$ without making any reference to the legal status of Western Sahara as an occupied territory or to the right of its people to self-determination. While the text of the 2016 Annual Report (which was adopted in October 2017, namely after the delivery of the CJEU's Front Polisario judgment) is more carefully drafted stating that Western Sahara is a 'non-self-governing territory, whose status remains the object of a negotiation process conducted under the auspices of the UN', ${ }^{55}$ it still omits any reference to its status as an occupied territory. In this light, the Western Sahara litigation clearly involved politically sensitive questions, and the Court was well aware of the potential impact of its pronouncements on EU-Morocco relations. The fact that Morocco temporarily suspended its diplomatic relations with the $\mathrm{EU}^{56}$ in the aftermath of the General Court's ruling in Front Polisario ${ }^{57}$ as well as the fact that both the Council and the Commission expressly referred to the political nature of the questions put forward to the Court, ${ }^{58}$ attest to sensitive political dimension of this line of case law.

\footnotetext{
${ }^{48}$ Human Rights Committee, Consideration of reports submitted by States parties under Article 40 of the Covenant, Sixth periodic reports of States parties due in 2008, Morocco, UN Doc. CCPR/C/MAR/6, 31 August 2015, para. 31.

${ }^{49}$ Human Rights Committee, Consideration of reports submitted by States parties under Article 40 of the Covenant, Fifth periodic report, Morocco, CCPR/C/MAR/2004/5, 11 May 2004, para. 39.

${ }^{50}$ Speech to the Nation by King Mohammed VI delivered on the occasion of the $39^{\text {th }}$ anniversary of the Green March, 06 November 2014, available at www.maroc.ma/en/royal-activities/hm-king-delivers-speech-nation-39th-anniversarygreen-march.

${ }^{51}$ Chinkin, supra note 42, at 198. M. Dawidowicz, supra note 39, at 272.

${ }^{52}$ EU Annual Report on Human Rights and Democracy in the World in 2014, 22 June 2015, 10152/15, 186.

${ }^{53} \mathrm{P}$. Wrange, Occupation/Annexation of a Territory: Respect for International Humanitarian Law and Human Rights and Consistent EU Policy, Study undertaken at the Request of the European Parliament, 25 June 2015, PE 534.995, 43, available at www.europarl.europa.eu/thinktank/en/document.html?reference=EXPO_STU(2015)534995.

${ }^{54}$ EU Annual Report on Human Rights and Democracy in the World in 2014, 86 (emphasis added).

${ }^{55} \mathrm{EU}$ Annual Report on Human Rights and Democracy in the World in 2016, 16 October 2017, 12816/17, 115.

${ }^{56} \mathrm{~A}$. El Yaakoubi, 'Morocco suspends contacts with EU over court ruling on farm trade', Reuters, 25 February 2016, available at uk.reuters.com/article/uk-eu-morocco-westernsahara/morocco-suspends-contacts-with-eu-over-court-rulingon-farm-trade-idUKKCN0VY273.

${ }^{57}$ Case T-512/12, Front Polisario v. Council of the European Union, [2015] ECLI:EU:T:2015:953.

${ }^{58}$ Opinion of Advocate General Wathelet, Case C-104/16 P, Council of the European Union v. Front populaire pour la libération de la saguia-el-hamra et du rio de oro (Front Polisario), [2016] ECLI:EU:C:2016:677, para. 141.
} 


\section{The Front Polisario case}

On 21 December 2016, the CJEU delivered its appeals judgment in the Front Polisario case. ${ }^{59}$ The Grand Chamber overturned the General Court's judgment ${ }^{60}$ rendered a year earlier. It decided that Front Polisario, the main Sahrawi liberation movement, did not have legal standing to bring an action for annulment against the Council decision ${ }^{61}$ adopting the 2010 EU-Morocco Agreement on agricultural, processed agricultural and fisheries products (Liberalization Agreement) 62 since, in its view, neither the Liberalization Agreement nor the 1996 EU-Morocco Association Agreement $^{63}$ (on which the former is based) legally extend to the territory of Western Sahara. ${ }^{64}$ The CJEU ruled that the General Court erred in interpreting the territorial scope of the Liberalization Agreement as extending to Western Sahara to the extent that it failed to take into account Article $31(3)(c)$ of the Vienna Convention on the Law of Treaties ${ }^{65}$ (VCLT) pursuant to which the interpretation of a treaty must be carried out in the light of 'any relevant rules of international law applicable in the relations between the parties' ${ }^{66}$ The Court pointed out three relevant rules of applicable international law that the General Court failed to take into account: the right to selfdetermination; Article 29 VCLT relating to the territorial scope of international agreements; and the principle of the relative effect of treaties (the principle of pacta tertiis). ${ }^{67}$

According to the Court, the right to self-determination is an erga omnes right and one of the essential principles of international law, as evidenced by the relevant case law of the ICJ, ${ }^{68}$ applicable to all non-self-governing territories and to all peoples who have not yet achieved independence. ${ }^{69}$ As a non-self-governing-territory whose peoples have an internationally recognized right to self-determination, Western Sahara has a legal status separate and distinct from that of Morocco, and this legal status precludes the legal application of Article 94 of the Association Agreement to the territory. ${ }^{70}$

Next, the Court turned to the 'territorial scope' rule enshrined in Article 29 VCLT. $^{71}$ In the Court's view, the wording of the article implies that an international agreement is applicable only within the geographical space within which a state exercises its full sovereign powers and does not extend to other territories under its jurisdiction or international responsibility, unless the treaty expressly provides for such an extension. ${ }^{72}$ This reading of Article 29 VCLT precluded Western

\footnotetext{
${ }^{59}$ Front Polisario, supra note 5.

${ }^{60}$ Case T-512/12, supra note 57. For analysis see E. Kassoti, 'The Front Polisario $v$ Council Case: The General Court, Völkerrechtsfreundlichkeit and the External Aspect of European Integration', (2017) 2 European Papers 339, available at europeanpapers.eu/en/system/files/pdf_version/EP_EF_2017_I_010_Eva_Kassoti_3.pdf.

${ }^{61}$ Council Decision of 8 March 2012 on the conclusion of an Agreement in the form of an Exchange of Letters between the European Union and the Kingdom of Morocco concerning reciprocal liberalization measures on agricultural products, processed agricultural products, fish and fishery products, the replacement of Protocols 1, 2 and 3 and their Annexes and amendments to the Euro-Mediterranean Agreement establishing an association between the European Communities and their Member States, of the one part, and the Kingdom of Morocco, of the other part OJ [2012] L 241.

${ }^{62}$ Agreement in the form of an Exchange of Letters between the European Community and the Kingdom of Morocco concerning reciprocal liberalization measures on agricultural products, processed agricultural products, fish and fishery products, the replacement of Protocols 1, 2 and 3 of and their Annexes and amendments to the Euro-Mediterranean Agreement establishing an association between the European Communities and their Member States, of the one part, and the Kingdom of Morocco, of the other part OJ [2012] L 241 (hereinafter the Liberalization Agreement).

${ }^{63}$ Euro-Mediterranean Agreement establishing an association between the European Communities and their Member States, of the one part, and the Kingdom of Morocco, of the other part OJ [2000] L 70 (hereinafter the Association Agreement).

${ }^{64}$ Front Polisario, supra note 5, paras. 92, 123, 132-3.

${ }^{65} 1969$ Vienna Convention on the Law of Treaties, 1155 UNTS 331.

${ }^{66}$ Front Polisario, supra note 5, para. 86.

${ }^{67}$ Ibid., para. 87.

${ }^{68}$ Ibid., para. 88. The CJEU cited the ICJ's Advisory Opinion on Western Sahara and the East Timor case. Western Sahara, supra note 33, paras. 54-6; Case concerning East Timor (Portugal v. Australia), [1995] ICJ Rep. 90, para. 29.

${ }^{69}$ Front Polisario, supra note 5, para. 88 .

${ }^{70}$ Ibid., paras. 89-92.

${ }^{71}$ Ibid., paras. 94-9.
} 
Sahara, as a non-self-governing territory, from being regarded as falling under Article 94 of the Association Agreement. ${ }^{73}$

In its analysis of the relevant rules of international law applicable between the EU and Morocco, the Court finally relied on the principle of the relative effect of treaties (pacta tertiis principle) enshrined in Article 34 VCLT. $^{74}$ It was asserted that Western Sahara's status as a non-self-governing territory means that it constitutes a third party (tertius) in relation to the EU and Morocco. ${ }^{75}$ Thus, the Association Agreement could not, in the Court's view, be interpreted as being applicable to the territory of Western Sahara to the extent that its people had not expressly consented thereto. ${ }^{76}$

Finally, the Court also disagreed with the General Court's assessment of the role of 'subsequent practice' in interpreting the Liberalization Agreement pursuant to Article 31(3)(b) VCLT. ${ }^{77}$ The CJEU held that the General Court failed to establish the requisite elements of Article 31(3)(b) VCLT. In the Court's opinion, the instances of de facto application of the Association and Liberalization Agreements to Western Sahara did not warrant the conclusion that the EU and Morocco had actually agreed to extend the application of those treaties to the territory in question. ${ }^{78}$ In the light of the finding that the Liberalization Agreement is not legally applicable to the territory of Western Sahara, the CJEU held that Front Polisario did not have legal standing to bring an action of annulment against the Council Decision approving the Liberalization Agreement and, accordingly, the Court dismissed its action as inadmissible. ${ }^{79}$

The judgment has been criticized in the literature mainly because of the CJEU's selective and artificial reliance on international law. ${ }^{80}$ More particularly, as Odermatt observes, the judgment is an example of the Court 'instrumentalizing' international law. ${ }^{81}$ Though purportedly relying on international law, upon closer scrutiny, the Court's reasoning and findings are far from convincing from the vantage point of the international legal order since the CJEU applied principles of international law without taking into consideration how these principles are actually understood in international law and in international judicial practice. In this sense, the Court's approach to international law in this case is difficult to reconcile with the EU's internationalist rhetoric. ${ }^{82}$

First, the Court's approach to treaty interpretation is problematic; here, the Court approached the question of interpretation of the territorial scope of the Association and Liberalization Agreements almost exclusively through the lens of Article 31(3)(c) VCLT (interpretation in the light of 'relevant rules of international law applicable in the relations between the parties'). ${ }^{83}$

\footnotetext{
${ }^{72}$ Ibid., paras. 94-6.

${ }^{73}$ Ibid., para. 97.

${ }^{74}$ Ibid., paras. $100-7$.

${ }^{75}$ Ibid., paras. 104-6.

${ }^{76}$ Ibid., paras. 106-7.

${ }^{77}$ Ibid., paras. 117-25. According to the text of Art. 31(3)(b) VCLT, account must be taken, together with the context, of 'any subsequent practice in the application of the treaty which establishes the agreement of the parties regarding its interpretation'.

${ }^{78}$ Front Polisario, supra note 5, paras. 121-2.

${ }^{79}$ Ibid., paras. 131-4.

${ }^{80}$ E. Kassoti, 'The Council v. Front Polisario Case: The Court of Justice's Selective Reliance on Treaty Interpretation', (2017) 2 European Papers 23, at 41. J. Odermatt, 'Council of the European Union v. Front populaire pour la libération de la saguia-elhamra et du rio de oro (Front Polisario). Case C-104/16P', (2017) 111 AJIL 731, at 737-8. G. Van der Loo, 'Law and Practice of the EU's Trade Agreements with Disputed Territories', in S. Garben and I. Govaere (eds.), The Interface between EU and International Law, (2019), 1, at 17. P. Hilpold, 'Self-Determination at the European Courts: The Front Polisario Case Or the Unintended Awakening of A Giant', (2017) 2 European Papers 907, at 908. However, according to De Elera: 'The legal analysis by the Court may seem, under international law, immaculate and is certainly much closer to the orthodoxy of international and Union law.' A. De Elera, 'The Frente Polisario Judgments: An Assessment in the Light of the Court of Justice's Case Law on Territorial disputes', in J. Czuczai and F. Naert (eds.), The EU as a Global Actor - Bridging Theory and Practice, Liber Amicorum in honour of Ricardo Gosalbo Bono (2017), 266, at 287.

${ }^{81}$ Odermatt, ibid., at 737.

${ }^{82}$ Kassoti, supra note 80 , at 27 . Van der Loo, supra note 69, at 17. Odermatt, ibid., at 738.

${ }^{83}$ Kassoti, ibid., at 29 . J. Odermatt, ibid., at 735.
} 
The Court's excessive reliance on Article 31(3)(c) VCLT and the fact that it paid little or no attention to other elements contained therein go against the interpretative process envisaged thereunder; a process that, according to the International Law Commission (ILC), is predicated on the combined application of all means of interpretation set out in Article $31 .^{84}$ The practice of international adjudicatory bodies confirms that interpretation under Article 31 VCLT is a legal operation that requires: (i) that all elements of the article should be evaluated together; and (ii) that no firm conclusion based on particular elements should be reached before the conclusion of the interpretative process. ${ }^{85}$ Rather than starting with the treaty terms and applying the whole process of the Vienna Convention systematically, the CJEU 'turned treaty interpretation on its head' and relied almost exclusively on Article 31(3)(c) VCLT. ${ }^{86}$ This not only shows unfamiliarity with the operation of Article 31 VCLT but also casts doubt on its findings.

Secondly, it is questionable to what extent the rules invoked and relied upon by the Court constitute in reality 'relevant rules of international law applicable in the relations between the parties' within the meaning of Article 31(3)(c) VCLT. The Court's reliance on the principle of selfdetermination of the peoples of Western Sahara, as a non-self-governing territory, for the purpose of interpreting the territorial scope of the EU-Morocco Association Agreement is particularly problematic. The Court found that the right of peoples to self-determination is a right erga omnes and as such it is applicable to the relations between the EU and Morocco. ${ }^{87}$ It then relied on the Friendly Relations Declaration, ${ }^{88}$ according to which a non-self-governing territory has 'under the [UN] Charter, a status separate and distinct from the State administering it', in order to conclude that the Association Agreement cannot be interpreted in such a way as to include Western Sahara within its territorial scope. ${ }^{89}$ The Court here drew conclusions regarding the territorial status of Western Sahara vis-à-vis Morocco without inquiring into the exact legal consequences that might flow from a non-self-governing-territory possessing 'separate and distinct status' ${ }^{90}$ The Friendly Relations Declaration reference to the 'separate and distinct' status of non-self-governing territories is generally understood to mean that these territories enjoy a measure of international legal personality, but not necessarily a measure of territorial sovereignty ${ }^{91}$ - as the CJEU seems to imply here. Indeed, there is evidence to suggest that, in the context of non-self-governing territories, sovereignty and territorial title remain with the administering state. ${ }^{92}$

Furthermore, it is difficult to see how the extract from the Friendly Relations Declaration is relevant for the purpose of interpreting what constitutes the 'territory of the Kingdom of Morocco'; the extract clearly refers to, and defines, the legal status of non-self-governing territories vis-à-vis their administering states. However, Morocco does not administer Western Sahara under Article 73 of the UN Charter but militarily occupies it. In this vein, Hilpold notes that:

in applying this principle (self-determination) to the Front Polisario case, the Court of Justice goes far beyond what was said by the International Court of Justice in 1995 (in the East Timor

\footnotetext{
${ }^{84}$ Draft Articles on the Law of Treaties with commentaries, text adopted by the International Law Commission at its $18^{\text {th }}$ session, 1966 Yearbook of the ILC, Vol. II, 219, para. 8.

${ }^{85}$ ICSID, Award of 21 October 2005, Case No ARB/02/03, Aquas del Tunari v. Bolivia, para. 91. Appellate Report European Communities - Customs Classification of Frozen Boneless Chicken Cuts, adopted 12 September 2005, AB-2005-5, para. 177.

${ }^{86}$ Kassoti, supra note 80, at 31. Odermatt, supra note 80, at 735.

${ }^{87}$ Front Polisario, supra note 5, paras. 88-9.

${ }^{88}$ Declaration on Principles of International Law concerning Friendly Relations and Co-operation among States in accordance with the Charter of the United Nations, UN Doc. A/RES/25/2625 (1970) (Friendly Relations Declaration).

${ }^{89}$ Front Polisario, supra note 5, para. 92.

${ }^{90} \mathrm{Kassoti}$, supra note 80 , at 32-4. Odermatt, supra note 80, at 735.

${ }^{91}$ J. Crawford, The Creation of States in International Law (2006), 618-19. A. Schwed, 'Territorial Claims as a Limitation to the Right to Self-Determination in the Context of the Falkland Islands Dispute', (1982) 6 Fordham International Law Journal 443 , at 452 .

${ }^{92}$ Crawford, ibid., at 613-15. V. Gowlland-Debbas, Collective Responses to Illegal Acts in International Law: United Nations Action in the Case of Southern Rhodesia (1990), 157.
} 
Case) and in 2004 (in the Wall Opinion) ... If applied coherently, this new rule would mean that the EU is prohibited from extending the territorial application of trade agreements to occupied regions whose population is denied their right to self-determination. ${ }^{93}$

It has been suggested in the literature that, despite its flawed reasoning, the judgment can still be perceived as völkerrechtsfreundlich particularly because the Court clearly reaffirmed Western Sahara's distinct territorial status, the right of self-determination of the Sahrawi people, and the erga omnes nature of such right. ${ }^{94}$ According to Milano this is so especially in the light of the fact that the role of the CJEU is not to cast light on complex issues of international law:

the CJEU is generally concerned with upholding and guaranteeing the consistency and coherence of the EU legal order, rather than contributing to the development of international law or projecting the image of the EU as a Völkerrechtsfreundlich actor. ${ }^{95}$

This proposition is problematic. Although the Court's reaffirmation of the right of the people of Western Sahara to self-determination is - in and of itself - commendable, it does not detract from the fact that the Court, in this case, applied international law rules of treaty interpretation in a way that few international lawyers would recognize. Respect for international law is now expressly a core constitutional norm - something that has been acknowledged by the Court itself. ${ }^{96}$ The EU's external projection of itself as an entity firmly committed to the strict observance and development of international law generates the expectation that its Courts also espouse something of this internationalist approach. ${ }^{97}$ The Court's misconstruction of international law in this case does not sit well with the image of a court that shares an internationalist outlook. Furthermore, misconstruing international law affects the legitimacy of the Court itself as a judicial body. Traditionally, an important source of legitimacy for the judiciary is a 'reason-based legitimacy', namely the convincing quality of its legal reasoning - something that 'results from the judges construing ... the law before them ... in a way that their judicial decisions sit coherently with the "relevant" existing legal propositions' ${ }^{98}$ In this light, the Court's interpretation of the principle of self-determination undermines its own reason-based legitimacy.

Similarly, the proposition that Article 29 VCLT supports the finding of legal inapplicability of the agreements at hand to the territory of Western Sahara is open to doubt. ${ }^{99}$ Here the Court relied on Article 29 VCLT in order to argue that whenever an international agreement is intended to produce extraterritorial effect, the wording of its 'territorial scope' clause is formulated in such a way as to expressly provide for this effect. ${ }^{100}$ Short of a provision expressly allowing the extraterritorial application of the Association Agreement to Western Sahara, it was concluded that its scope could not be understood as including that territory. ${ }^{101}$ The Court's argument to the effect

\footnotetext{
${ }^{93}$ Hilpold, supra note 80 , at $918,920$.

${ }^{94}$ E. Milano, 'Front Polisario and the Exploitation of Natural Resources by the Administrative Power', (2017) 2 European Papers 953, at 966.

${ }^{95}$ Ibid., at $965-6$.

${ }^{96}$ Case C-366/10, Air Transport Association for America v. Secretary of State for Energy and Climate Change, [2011] EU: C:2011:864, para. 101 and Joined cases C-584/10 P, C-593/10 P and C-595/10 P, Commission and Others v. Kadi, [2013] EU: C:2013:518, para. 103 .

${ }^{97}$ G. De Búrca, 'After the EU Charter of Fundamental Rights: The Court of Justice as a Human Rights Adjudicator?', (2013) 20 Maastricht Journal of European and Comparative Law 168, at 183.

${ }^{98} \mathrm{C}$. Eckes, 'International Rulings and the EU Legal Order: Autonomy as Legitimacy?', CLEER, available at www.asser.nl/ media/3002/cleer16-2_complete_web.pdf. According to MacCormick: 'Not merely must a decision be justified by good argumentation from consequences and/or from principle or analogy. It must also be shown to be not inconsistent with established rules.' N. MacCormick, Legal Reasoning and Legal Theory (1978), 196.

${ }^{99}$ Kassoti, supra note 80 , at $34-5$. Odermatt, supra note 80 , at 736.

${ }^{100}$ Front Polisario, supra note 5, paras. 94-6.

${ }^{101}$ Ibid., paras. $95-7$.
} 
that Article 29 VCLT creates a presumption against extraterritoriality does not comport with the drafting history of the Article. The ILC, in its 1966 commentary, made it abundantly clear that the matter of extraterritorial application of treaties was too complicated and it decided to leave it aside. ${ }^{102}$ Furthermore, as Odermatt stresses, according to the ILC, Article 29 VCLT was designed to apply in cases where a treaty does not define its territorial application - something that is not the case in relation to the agreement at hand. ${ }^{103}$ In this light, the Court's conclusion that Article 29 VCLT corroborates the view that the territorial scope of the Association Agreement does not extend to Western Sahara seems unsubstantiated.

The CJEU's interpretation and application of the principle of the relative effect of treaties (pacta tertiis principle) has also been criticized in the literature to the extent that the applicability of this principle to international legal persons other than states remains unclear. ${ }^{104}$ The principle's conceptual roots in the notions of state sovereignty and sovereign equality arguably preclude its application to non-state actors. The principle has been codified in Article 34 VCLT which clearly refers to 'third States' and not to 'third parties' in general, and the ILC in its 1966 commentary highlighted the rule's intrinsic link to the notion of state sovereignty. ${ }^{105}$ In the light of the statecentric nature of the principle, the Court's unqualified assertion that it applies to relations between states and non-state actors falls short of convincing.

The overwhelming majority of commentators have found the Court's reluctance to engage extensively with the parties' 'subsequent practice in the application of the treaty' under Article 31(3)(b) VCLT for the purpose of interpreting the territorial scope of the Association and Liberalization Agreement particularly problematic. ${ }^{106}$ The importance attached to the subsequent practice of the parties to a treaty in its interpretation constitutes one of the most distinctive features of the Vienna rules. ${ }^{107}$ International courts and tribunals routinely have recourse to the subsequent practice of the parties in order to establish the 'ordinary meaning' of a treaty term in accordance with Article 31(1) VCLT, or it can enter the reasoning at a later stage, in order to confirm the result reached from the initial textual interpretation. ${ }^{108}$ The CJEU has also recognized the relevance of the 'settled practice of the parties to the Agreement' for the purpose of treaty interpretation, ${ }^{109}$ and it has even argued that 'the subsequent practice followed in the application of a treaty may override the clear terms of that treaty if that practice reflects the parties' agreement'. ${ }^{110}$ The Court's refusal to engage with the parties' subsequent practice severely undermines the outcome of its interpretative process. In a similar vein, the Court's dismissal of subsequent conduct by the EU and Morocco as mere de facto instances of application of the agreements at hand to the territory of Western Sahara ${ }^{111}$ falls short of convincing since the Court failed to make a

\footnotetext{
${ }^{102}$ International Law Commission (ILC) Draft Articles on the Law of Treaties with commentaries, adopted by the ILC at its $18^{\text {th }}$ session in 1966, 1966 Yearbook of the ILC, at 213-14, para. 5.

${ }^{103}$ Odermatt, supra note 80, at 736. ILC Draft Articles on the Law of Treaties with commentaries, ibid., at 213, para. 2.

${ }^{104}$ C. Ryngaert, 'The Polisario Front Judgment of the EU Court of Justice: A Reset of EU-Morocco Trade Relations in the Offing', Reinforce blog, available at blog.renforce.eu/index.php/nl/2017/01/15/the-polisario-front-judgment-of-the-eu-courtof-justice-a-reset-of-eu-morocco-trade-relations-in-the-offing; Hilpold, supra note 80, at 917; Kassoti, supra note 80, at 35-7; Odermatt, supra note 80, at 736; Van der Loo, supra note 80, at 17.

${ }^{105}$ ILC Draft Articles on the Law of Treaties with commentaries, supra note 102, at 226, para. 1.

${ }^{106}$ E. Cannizzaro, 'In Defence of Front Polisario: The ECJ as a Global Jus Cogens Maker', (2018) 55 Common Market Law Review 569, at 578; Hilpold, supra note 80, at 917; Kassoti, supra note 80, at 37-40; Odermatt, supra note 80, at 737; Van der Loo, supra note 80 , at 16 .

${ }^{107}$ ILC Draft Articles on the Law of Treaties with commentaries, supra note 102, at 221, para. 15.

${ }^{108}$ See for example Case concerning Kasikili/Seduku Island (Botswana v. Namibia), Judgment of 13 December 1999 [1999] ICJ Rep. 1045, para. 50. Appellate Report Japan - Taxes on Alcoholic Beverages, adopted 4 October 1996, AB-1996-2, at 12-13.

${ }^{109}$ Case C-52/77, Leonce Cayrol v. Giovanni Rivoira \& Figli, [1977] EU:C:1977:196, para. 18; Anastasiou, supra note 3 , paras. 43,50 .

${ }^{110}$ Case C-464/13, Europäische Schule München v Silvana Oberto and Barbara O'Leary, [2015] EU:C:2015:163, para. 61.

${ }^{111}$ Front Polisario, supra note 5, para. 121.
} 
distinction between 'de facto instances of application of an agreement' and 'subsequent practice' within the meaning of Article 31(3)(b) VCLT.

In this context, the sole argument provided by the Court was that the de facto application of the agreements to the Western Sahara did not reflect the existence of an agreement between the EU and Morocco with regard to interpretation as required by Article 31(3)(b) VCLT. ${ }^{112}$ According to the Court, had the EU intended the agreements to apply to Western Sahara, that:

would necessarily have entailed conceding that the European Union intended to implement those agreements in a manner incompatible with the principles of self-determination and of the relative effect of treaties, even though the European Union repeatedly reiterated the need to comply with those principles. ${ }^{113}$

The Court's tortured logic according to which 'there could not be what must not be'114 has been vociferously criticized in the literature. ${ }^{115}$ As Van der Loo aptly notes: 'the reasoning of the Court is based on the remarkable assumption that it is unthinkable that the EU would not act in good faith or contrary to international law. ${ }^{116}$

In the literature, an argument has been floated to the effect that the Court's prioritization of contextual interpretation (Article 31(3)(c) VCLT over subsequent practice (Article 31(3)(b) VCLT) ) is defensible from the vantage point of international law in the light of the interpretative relevance of the jus cogens nature of the principle of self-determination. ${ }^{117}$ According to Cannizzaro: 'The higher rank of self-determination provides an excellent reason for giving priority to the technique of contextual interpretation over the competing technique of subsequent practice. ${ }^{118}$ In this view, the existence of a peremptory norm in the normative environment within which a treaty is interpreted constitutes a 'legally insurmountable limit to a permissible treaty interpretation' ${ }^{\prime 19}$ leading the interpreter to construe a treaty provision consistently with the relevant peremptory norm.

With respect, it is submitted that this view is problematic on a number of grounds. First, this proposition does not find support in the Vienna rules which only envisage the operation of jus cogens norms as a body of rules from which no derogation is permitted (Article 53 VCLT). The general rule of interpretation as reflected in Article 31 VCLT does not carve out a special role for peremptory norms in the context of treaty interpretation. Second, this view is premised on the idea that the different means of interpretation enshrined in Article 31 VCLT are 'competing' or are (actually or potentially) in conflict with each other. As the argument goes, interpretation on the basis of the different means listed under Article 31 could yield different interpretative outcomes and thus, a conflict settling-rule (jus cogens) is needed in order to give priority to one of the competing means of interpretation. ${ }^{120}$ However, the conceptualization of the different means of interpretation under Article 31 VCLT as 'competing' or as in (actual or potential) conflict goes against the way in which the general rule of interpretation was designed to operate. According to the ILC $^{121}$ and to international judicial practice ${ }^{122}$ all elements of Article 31

\footnotetext{
${ }^{112}$ Ibid., paras. $121-2$.

${ }^{113}$ Ibid., para. 123.

${ }^{114}$ Hilpold, supra note 80, at 916.

${ }^{115}$ Cannizzaro, supra note 106, at 12; Van der Loo, supra note 80 , at 16; Odermatt, supra note 80 , at 737.

${ }^{116}$ Van der Loo, ibid., at 16.

${ }^{117}$ Cannizzaro, supra note 106 , at $578-80$.

${ }^{118}$ Ibid., at 580 .

${ }^{119}$ Oil Platforms Case (Islamic Republic of Iran v. United States of America), Judgment of 6 November 2003, [2003] ICJ

Rep. 324, at 330, para. 9 (Judge Simma, Separate Opinion).

${ }^{120}$ Cannizzaro, supra note 106 , at 579.

${ }^{121}$ ILC Draft Articles on the Law of Treaties with commentaries, supra note 102, at 219, para. 8.
} 
VCLT need to be viewed and applied together in a single combined operation, so that there is a single route to the interpretative outcome. ${ }^{123}$ In this sense, the very idea of 'conflicting means of interpretation' within the general rule departs from the process of interpretation as envisaged in the Vienna Convention. Third, taken to the extreme, this view would hold that in all cases where there is a discrepancy between law and fact, i.e., between the normative context of the agreement and the subsequent practice of the parties, this discrepancy could simply be papered over at the stage of interpretation - irrespective of the actual evidence on the ground.

Overall, the CJEU's artificial and selective reliance on international law in the Front Polisario case leaves much to be desired from an international legal perspective. In this case, the Court showed its willingness to stretch the limits of treaty interpretation to a breaking point in order to avoid pronouncing on the politically sensitive question of the de facto application of the agreements in question to the territory of Western Sahara. ${ }^{124}$

\section{The Western Sahara Campaign UK case}

The judgment followed a request for a preliminary ruling by the High Court of England and Wales in a case brought by Western Sahara Campaign UK, a voluntary organization whose aim is to support the right of the peoples of Western Sahara to self-determination. ${ }^{125}$ In the context of the national proceedings the applicant challenged the validity of the EU-Morocco Association Agreement, the Fisheries Partnership Agreement (FPA), ${ }^{126}$ the 2013 Fisheries Protocol ${ }^{127}$ as well as the relevant EU implementing legislation insofar as these instruments were applicable to the territory of Western Sahara and to the waters adjacent thereto. ${ }^{128}$ According to the applicant, the inclusion of that territory and of those waters within the territorial scope of the relevant EU-Morocco agreements violates Article 3(5) of the Treaty on European Union (TEU), under which the Union is required to respect international law. ${ }^{129}$ More particularly, the applicant claimed that such inclusion is incompatible with the right to self-determination, the duty of non-recognition, the duty of non-assistance as well as the principle of permanent sovereignty over natural resources. ${ }^{130}$ Since the preliminary ruling request was lodged before the judgment in the Front Polisario case was delivered, the referring court withdrew its first two questions regarding the interpretation and validity of the Association Agreement following the delivery of the Front Polisario judgment. ${ }^{131}$ In this light, the two questions that remained to be answered concerned: (i) the validity of the FPA and the 2013 Protocol as well as the relevant EU implementing acts having regard to Article 3(5) TEU; and (ii) the conditions under which international law may

\footnotetext{
${ }^{122}$ S. Torres Bernárdez, 'Interpretation of Treaties by the International Court of Justice following the Adoption of the 1969 Vienna Convention on the Law of Treaties', in G. Hafner et al. (eds.), Liber Amicorum Ignaz Seidl-Hohenveldern in honour of his 80th Birthday (1998), 721, at 726.

${ }^{123}$ R. Gardiner, Treaty Interpretation (2015), at 30-2. M. Villiger, 'The Rules on Interpretation: Misgivings, Misunderstandings, Miscarriage? The "Crucible" Approach Intended by the International Law Commission', in E. Cannizzaro (ed.), The Law of Treaties Beyond the Vienna Convention (2011), 105, at 114.

${ }^{124}$ Kassoti, supra note 80 , at 41 . Odermatt, supra note 80 , at 737-8.

${ }^{125}$ Western Sahara Campaign UK, supra note 1, paras. 30-1.

${ }^{126}$ Fisheries Partnership Agreement between the European Community and the Kingdom of Morocco, OJ [2006] L141/4.

${ }^{127}$ Protocol between the European Union and the Kingdom of Morocco setting out the fishing opportunities and the financial contribution provided for in the Fisheries Partnership Agreement between the European Union and the Kingdom of Morocco, OJ [2013] L328/2.

${ }^{128}$ Western Sahara Campaign UK, supra note 1, para. 32.

${ }^{129}$ Ibid., para. 32.

${ }^{130}$ Ibid., para. 32. Opinion of A.G. Wathelet, Western Sahara Campaign UK, supra note 47, para. 26.

${ }^{131}$ Western Sahara Campaign UK, supra note 1, paras. $39-40$.
} 
be relied on in the context of judicial review of EU acts by a request for a preliminary ruling on validity. ${ }^{132}$

In this case, the Court set out to interpret the territorial scope of the FPA and the 2013 on the basis of international rules of treaty interpretation. However, as in Front Polisario, the Court's approach to treaty interpretation in this case is highly problematic from an international law point of view. Four main points pertaining to the Court's problematic approach to treaty interpretation are made below. First, the Court here ascribed undue weight to the assumption that the EU could not have acted in breach of international law - a line of reasoning that does not comport with the letter and spirit of the Vienna rules. Second, in a similar vein of the Front Polisario judgment, the Court's excessive reliance on Article 31(3)(c) and its refusal to engage with the other means of interpretation enshrined therein cast doubt on its findings. Third, the cumulative effect of these two aforementioned lines of argumentation is that the Court focused excessively on the normative context of the agreements, thereby losing sight of the main aim of treaty interpretation, i.e., discerning the common intention of the parties. Fourth, the eschewal of engagement with the subsequent practice of the parties renders the Court's interpretative outcome questionable.

As seen above, one of the most striking aspects of the Front Polisario judgment - and one that has attracted a fair amount of criticism in the literature - was the Court's over-reliance on the normative context of the dispute for the purposes of interpreting the EU-Morocco Association and Liberalization Agreements. ${ }^{133}$ More particularly, in Front Polisario, the Court advanced, inter alia, the argument that since the EU has expressly professed its respect to international law, then the relevant agreements must be interpreted in a way that assumes that the EU respects international law. ${ }^{134}$ The same argument to the effect that 'there could not be what must not be ${ }^{\text {'135 }}$ permeates the Western Sahara Campaign UK judgment. The Court had recourse to this argument twice; both in interpreting what constitutes the concept of 'territory' of Morocco and in interpreting what constitutes 'waters falling within the sovereignty' of Morocco. According to the judgment, if the EU-Morocco fisheries agreements extended to the territory of Western Sahara and the waters adjacent thereto, 'this would be contrary to certain rules of international law ... which the European Union must observe'. ${ }^{136}$

This line of reasoning is deeply problematic on a number of grounds. The extreme version of the argument advanced by the Court holds that the EU could never be found in breach of international law simply because this would run counter to its express commitment to upholding international law and irrespective of the actual evidence on the ground. In this sense, in the context of judicial review of the compatibility of the EU's international agreements with international law, all conflicts between what the EU should do according to international law and what it actually does in the application of an agreement could simply be 'interpreted away'.

More fundamentally, this line of reasoning raises questions in relation to the weight and role that such an assumption may have in the process of treaty interpretation. To be sure, in the context of treaty interpretation, there is a presumption that in entering treaty obligations, the parties intend not to act inconsistently with generally recognized principles of international law. ${ }^{137}$ However, this is merely a presumption, namely the starting point in the quest for attributing meaning to the relevant treaty terms, and thus, it cannot, in and of itself, displace the actual interpretative process. As Jenks writes:

\footnotetext{
${ }^{132}$ Ibid., para. 41; Opinion of A.G. Wathelet, Western Sahara Campaign UK, supra note 47, para. 40.

${ }^{133}$ Kassoti, supra note 80, at 29-37; Hilpold, supra note 80, at 916; Van der Loo, supra note 80, at 14-17.

${ }^{134}$ Front Polisario, supra note 5, para. 123; Odermatt, supra note 80, at 737.

${ }^{135}$ Hilpold, supra note 80 , at 916.

${ }^{136}$ Western Sahara Campaign UK, supra note 1, paras. 63, 71.

${ }^{137}$ Case concerning Right of Passage over Indian Territory (Portugal v. India), Preliminary Objections, Judgment of 26 November 1957, [1957] ICJ Rep. 125, at 142.
} 
the presumption against conflict is not, however, of an overriding character. It is one of the elements to be taken into account in determining the meaning of a treaty provision, but will not avail against clear language or clear evidence of intention. ${ }^{138}$

Here the Court seems to have accorded undue weight to the presumption of compliance with international law. The EU's professed commitment to international law was not treated merely as the starting point in the quest for ascertaining the meaning of the relevant treaty terms in the FPA, but as an overriding principle of treaty interpretation. This approach, however, does not comport with the interpretative process under Article 31 VCLT.

Furthermore, the argument, according to which 'there could not be what must not be', seems to conflate interpretation with application. Although closely intertwined, these two normative processes are distinct. ${ }^{139}$ Interpretation is the process of determining 'the meaning of a text', whereas application is 'the process of determining the consequences which, according to the text, should follow in a given situation'. ${ }^{140}$ Thus, interpretation, at least in the relatively strict sense referred to in the VCLT, is 'a matter of definition', ${ }^{141}$ namely a matter of giving meaning to the terms of a treaty. ${ }^{142}$ In international judicial practice, interpretation precedes the application of a treaty text. ${ }^{143}$ As Schwarzenberger put it: 'any application of a treaty, including its execution, presupposes ... a preceding conscious or subconscious interpretation of the treaty'. ${ }^{144}$ The distinction between the normative processes of interpretation and application is also relevant in demonstrating the inherent limitations of Article 31(3)(c) VCLT (interpretation in the light of 'relevant rules of international law'). It is one thing to seek interpretative guidance from the general principles of international law in order to clarify the meaning of a treaty term, and quite another to apply these principles independently of interpretation. ${ }^{145}$ As Gardiner notes:

Located in its immediate context of treaty interpretation, article 31(3)(c) implicitly invites the interpreter to draw a distinction between using rules of international law as part of the apparatus of treaty interpretation and applying the rules of international law directly to the facts in the context of which the treaty is being considered. The former is within the scope of the Vienna rules, the latter not. ${ }^{146}$

In this light, the CJEU in the Western Sahara Campaign UK case put the cart before the horse by blurring the lines between interpretation and application. Here, the Court set out to interpret the terms 'territory' of Morocco and 'waters falling within the sovereignty' of Morocco, but it did so by directly applying the principle of self-determination and the principle of relative effect of treaties to

\footnotetext{
${ }^{138}$ W. Jenks, 'The Conflict of Law-Making Treaties', (1953) 30 BYIL 401, at 403.

${ }^{139}$ Case concerning Oil Platforms (Islamic Republic of Iran v. United States of America), Counter-claims, Judgment of 6 November 2003, [2003] ICJ Rep. 225, at para. 49 (Separate Opinion, Judge Higgins). See also generally A. Gourgourinis, 'The Distinction between Interpretation and Application of Norms in International Adjudication', (2011) 2 JIDS 31.

${ }^{140}$ Harvard Law School, 'Draft Convention on the Law of Treaties: Article 19. Interpretation', (1935) 29 American Journal of International Law Supplement 937, at 938-9. See also Case concerning the Factory at Chorzow, Jurisdiction, Judgment of 26 July 1927, PCIJ Rep Series A No 9, 35 at 39 (Dissenting Opinion Ehrlich); G. Haraszti, Some Fundamental Problems in the Law of Treaties (1973), 18.

${ }^{141}$ Fisheries Jurisdiction Case (Spain v. Canada), Jurisdiction, Judgment of 4 December 1998, [1998] ICJ Rep. 432, at para. 68.

${ }^{142}$ J. Pauwelyn, Conflict of Norms in Public International Law: How WTO Law Relates to Other Rules of International Law (2003), at 245.

${ }^{143}$ Applicability of the Obligation to Arbitrate under Section 21 of the United Nations Headquarter Agreement of 26 June 1947, Advisory Opinion of 26 April 1988, [1998] ICJ Rep. 57, at 59 (Separate Opinion, Judge Shahabuddeen).

${ }^{144} \mathrm{G}$. Schwarzenberger, 'Myths and Realities of Treaty Interpretation: Articles 27-29 of the Vienna Draft Convention on the Law of Treaties', (1969) 22 Current Legal Problems 205, at 212.

${ }^{145}$ Appellate Report, supra note 85, para. 177; Gourgourinis, supra note 139, at 51.

${ }^{146}$ Gardiner, supra note 123 , at 320 .
} 
the facts of the case. Having concluded that the application of those principles would lead to a finding of breach by the EU of its international law obligations, the Court reverted back to the process of interpretation and informed the meaning of the relevant treaty terms on the basis of the juridical consequences resulting from the application of the relevant rules. Thus, in essence, the Court here reversed the sequence of the interpretation-application processes in order to reach a conclusion that would not entail the breach by the EU of any of its international law obligations. By doing so, the Court blurred the distinction between clarifying the meaning of a treaty provision with reference to rules of international law and applying those rules directly to the facts in the context of which a treaty is being considered - the latter being impermissible under the Vienna rules. ${ }^{147}$ This greatly weakens the persuasive value of the Court's argumentation.

Another aspect of the judgment which is strongly reminiscent of the approach to treaty interpretation espoused in Front Polisario ${ }^{148}$ is the Court's exclusive reliance on Article 31(3)(c) VCLT (interpretation in the light of 'relevant rules of international law') for the purpose of interpreting the term 'waters falling within the jurisdiction' of Morocco. Here, the Court relied exclusively on Articles 55 and 56 UNCLOS in order to interpret the territorial clause of the FPA and did not engage at all with the other means of interpretation listed in Article 31 VCLT. The Court's excessive reliance on Article 31(3)(c) VCLT and the fact that it did not take into account the other means of interpretation contained in the Article go against the 'crucible approach' intended by the ILC and employed in international judicial practice. ${ }^{149}$ As seen earlier, this 'crucible approach' envisages interpretation as a holistic process where the interpretative outcome results from the combined interaction of all elements contained in Article 31 VCLT. ${ }^{150}$ As Abi-Saab succinctly remarked, interpretation as a holistic process means:

[O]ne integrated operation which uses several tools simultaneously to shed light from different angles on the interpreted text; these tools should not be seen as watertight compartments or as a series of separate sub-operations but, rather, as connected (even overlapping) and mutually reinforcing parts of a whole, of a continuum or a continuous and multifaceted process that cannot be reduced to a mechanical operation and which partakes as much of art (the art of judgment) as of science (the science of law). ${ }^{151}$

In a similar vein to Front Polisario, the Western Sahara Campaign UK judgment does not show any evidence of this holistic process to treaty interpretation. By relying exclusively on Article $31(3)(c)$ VCLT) in order to ascertain the meaning of the term 'waters falling within the jurisdiction of Morocco', the Court adopted an interpretative approach that significantly departs from the letter and spirit of the Vienna rules.

Apart from the individual flaws in the Court's approach to treaty interpretation, as these were identified and discussed above, the cumulative effect of these two main lines of argumentation (namely the over-reliance on the EU's expressed commitment to international law, and the excessive focus placed on Article 31(3)(c) VCLT) not only casts doubt on its findings but also raises questions about the Court's understanding of the main aim of treaty interpretation. The interpretative process, at least under the VCLT, ultimately aims at identifying the common intention of the parties. ${ }^{152}$ As Crawford highlights: 'It is too often forgotten that the parties to a treaty, that is the

\footnotetext{
${ }^{147}$ Ibid., at 320 .

${ }^{148}$ Kassoti, supra note 80 , at $30-1$.

${ }^{149}$ See above notes 110 and 111.

${ }^{150}$ Gardiner, supra note 123 , at 32 .

${ }^{151}$ G. Abi-Saab, 'The Appelate Body and Treaty Interpretation', in G. Sacerdoti, A. Yanovich and J. Bohanes (eds.), The WTO at Ten - The Contribution of the Dispute Settlement System (2006), 453, at 459.

${ }^{152} \mathrm{ILC}$, Report on Subsequent Agreements and Subsequent Practice in relation to the Interpretation of Treaties, UN Doc. A/68/10 (2013), 27; Dispute regarding Navigational and Related Rights (Costa Rica v. Nicaragua), Judgment of 13 July 2009, [2009] ICJ Rep. 213, at para. 58.
} 
states which are bound by it at the relevant time, own the treaty. It is their treaty. It is not anyone else's treaty.' 153 The common intention of the parties is a construct to be derived in the process of interpretation by having recourse to the means of interpretation enshrined in Article 31 VCLT. ${ }^{154}$ In this light, in interpreting the territorial scope of the FPA and the 2013 Protocol, the sole relevant question is whether the common intention of the EU and Morocco, as evidenced (i) by the ordinary meaning of the terms of these two treaties; (ii) in their context and (iii) in the light of the treaties' object and purpose, was that the territory were included therein.

However, in Western Sahara Campaign UK, the Court seems to have lost sight of the main aim of treaty interpretation. Here, by focusing exclusively on the normative context of the dispute, the enquiry into the common intention of the parties was replaced with an enquiry into why Western Sahara should not have been included in the territorial scope of the agreements at hand. To be sure, there are many good reasons why the territory should have been excluded from the territorial scope of the EU-Morocco fisheries agreements. ${ }^{155}$ This is, however, beside the point. The crucial question in this context is whether the parties intended to include Western Sahara in their agreements - and not whether what they intended was contrary to international law.

As discussed above, the overwhelming majority of commentators have found the Court's reluctance to engage extensively with the parties' 'subsequent practice in the application of the treaty' under Article 31(3)(b) VCLT in the context of the Front Polisario case particularly problematic. ${ }^{156}$ The same reluctance to engage with the parties' subsequent practice for the purpose of interpreting the territorial scope of the FPA and the 2013 Protocol permeates the Court's judgment in Western Sahara Campaign UK.

The ILC accorded particular importance to 'subsequent practice' characterizing it as an 'authentic means of interpretation' ${ }^{\text {' } 57}$ since 'it constitutes objective evidence of the understanding of the parties as to the meaning of the treaty'. ${ }^{158}$ The Special Rapporteur on the Law of Treaties, Waldock, stated in his Third Report on the Law of Treaties: 'Subsequent practice when it is consistent and embraces all the parties would appear to be decisive of the meaning to be attached to the treaty. ${ }^{\prime 159}$ Treaty terms are given meaning by action and thus, the subsequent practice of the parties is the best evidence of their intention. ${ }^{160}$ The ILC, in its recent work on subsequent agreements and subsequent practice in treaty interpretation, has confirmed that the characterization of subsequent practice as an 'authentic means of interpretation' implies that Article 31(3)(b) possesses considerable authority as a means of interpretation. ${ }^{161}$ This proposition is borne out by international judicial practice. ${ }^{162}$ Here, the Court's eschewal of engagement with the normative significance of the subsequent practice of the parties does not reflect the importance attached thereto in theory and in practice as an authoritative indicator of the parties' common understanding of the relevant treaty terms.

\footnotetext{
${ }^{153}$ J. Crawford, 'A Consensualist Interpretation of Article 31(3) of the Vienna Convention on the Law of Treaties', in G. Nolte (ed.), Treaties and Subsequent Practice (2013), 29, at 31 (emphasis added).

${ }^{154}$ ILC Draft Articles with commentaries, supra note 102, at 218-19.

${ }^{155}$ The A.G.'s opinion offers a detailed exposition of the rules of international law breached by the inclusion of the territory in the territorial scope of the agreements. Opinion of A.G. Wathelet, Western Sahara Campaign UK, supra note 47, paras. 143-292.

${ }^{156}$ Cannizzaro, supra note 106, at 578; Kassoti, supra note 80, at 37-40; Odermatt supra note 80, at 717; Hilpold, supra note 80 , at 917 .

${ }^{157}$ Report of the ILC on the work of its $16^{\text {th }}$ session, 11 May - 24 July 1964, 1964 Yearbook of the ILC, Vol. II, 203, para. 13.

${ }^{158}$ ILC Draft Articles with commentaries, supra note 102, at 221, para. 15.

${ }^{159} \mathrm{H}$. Waldock, Third Report on the Law of Treaties, 1964 Yearbook of the ILC, Vol. II, 60, para. 25 (emphasis added).

${ }^{160}$ Gardiner, supra note 123, at 253; B. Simma, 'Miscellaneous Thoughts on Subsequent Agreements and Subsequent Practice', in Nolte, supra note 142, at 46.

${ }^{161}$ Report of the ILC on the work of its $65^{\text {th }}$ session, 6 May -7 June and 8 July -9 August 2013, UN Doc. A/68/10 (2013), $21-2$.

${ }^{162}$ See the overview provided in G. Nolte, First Report on Subsequent Agreements and Subsequent Practice in relation to treaty interpretation, UN Doc. A/CN.4/660 (2013), paras. 31-41.
} 
Overall, the CJEU in Western Sahara Campaign UK followed the same judicial strategy as in Front Polisario, namely one of 'instrumentalization' of international law. In both cases, the Court relied selectively on international law rules of treaty interpretation in order to limit the applicability of the EU-Morocco's agreements to the territory of the latter - while ignoring the factual application of these agreements to the territory and waters adjacent to Western Sahara. Furthermore, in both cases, the Court employed international law principles without actually considering how these are understood or applied by international courts and tribunals. ${ }^{163}$

It is safe to assume that the Western Sahara judgments have political overtones - especially, if one considers the context within which they were rendered. By omitting any reference to the legal status of Western Sahara as a territory occupied by Morocco - something, which, as seen earlier, Morocco strongly denies - the EU has managed to enter into a number of agreements with Morocco, and has managed to enter into and maintain trade relations with Morocco without touching upon the thorny question of Moroccan sovereignty over the territory. By a priori excluding the legal applicability of the agreements to Western Sahara on the basis of formalistic argumentation, the Court managed to avoid pronouncing thereon - in a rather overt attempt to achieve conformity with international law without having to pronounce on the legal repercussions of the EU's policy and practice towards Western Sahara. ${ }^{164}$

\section{Conclusion: The Völkerrechtsfreundlichkeit debate in the light of the CJEU's case law relating to economic agreements covering occupied territories}

The article showed that the Court's approach to international law in cases involving economic agreements covering occupied territories is highly problematic. While in its earlier case law the CJEU adopted a formalistic and one-dimensional approach to international law, its more recent jurisprudence evidences a more worrisome trend. In Front Polisario and in Western Sahara Campaign UK, the Court showed that it is prepared to use international law in ways that few international lawyers would recognize in order to avoid pronouncing on politically charged questions. The Court's willingness to rely on international law principles without actually taking into account how these principles are understood and applied by international courts and tribunals brings in another dimension in the Völkerrechtsfreundlichkeit debate. In the literature, one may find diametrically opposed accounts regarding the Court's openness to international law. ${ }^{165}$ At the same time, the classic, binary understanding of the Court's approach as 'open/hostile' to international law largely refers to the Court's attitude when confronted with questions of validity, direct effects and supremacy. ${ }^{166}$ Far less attention has been paid to how the Court actually uses international law in its case law and in particular, whether its own version of international law is reconcilable with that accepted by the interpretive community of international lawyers. ${ }^{167}$ The Court's apparent willingness to rely on international law as a heuristic device to reinforce an outcome that radically departs from the logic and structure of international law means that, in order for the Völkerrechtsfreundlichkeit discussion to remain relevant and accurate, a more in-depth engagement with the content of the international law rules invoked and with the Court's use thereof is required.

\footnotetext{
${ }^{163}$ Odermatt, supra note 80 , at 737-8.

${ }^{164}$ C. Rygnaert and R. Fransen, 'EU Extraterritorial Obligations with respect to trade with occupied territories: Reflections after the case of Front Polisario before EU courts', (2018) Europe and the World: A Law Review 1, at 19.

${ }^{165}$ J. Klabbers, 'The Reception of International Law in the EU Legal Order', in R. Schütze and T. Tridimas (eds.), Oxford Principles of European Union Law: Volume I: The European Union Legal Order (2018), at 1208.

${ }^{166} \mathrm{R}$. Wessel, 'Reconsidering the Relationship between International and EU Law: Toward a Content-Based Approach?', in Cannizzaro, Palchetti and Wessel, supra note 2, 7, at 18.

${ }^{167} \mathrm{~J}$. Klabbers, 'Völkerrechtsfreundlichkeit? International Law and the EU Legal Order', in P. Koutrakos (ed.), European Foreign Policy (2011), 95, at 111.
} 
Furthermore, the Court's reconceptualization of international rules of treaty interpretation (to put it mildly) in Front Polisario and in Western Sahara Campaign UK, raises serious questions regarding the way in which the Court handles politically sensitive issues. In both judgments the Court's unilateral re-interpretation of international law was clearly geared towards shielding the EU from the legal consequences stemming from its policy towards Western Sahara. At the very minimum, this line of case law should raise a few eyebrows over the extent to which the Court performed its judicial function in a proper manner. On the international plane, few disputes have no political ramifications. As the ICJ put it:

[T] he fact that a legal question also has political aspects, "as, in the nature of things, is the case with so many questions which arise in international life", does not suffice to deprive it of its character as a "legal question" and to "deprive the Court of a competence expressly conferred on it by its Statute..." Whatever its political aspects, the Court cannot refuse to admit the legal character of a question which invites it to discharge an essentially judicial function ... ${ }^{168}$

Displaying a cavalier attitude towards international law in politically sensitive cases not only threatens the Court's own legitimacy, but also undermines 'respect for international law' as a core constitutional value of the EU, thereby undermining the image of the EU as a global actor with a particular fidelity to international law.

${ }^{168}$ Legal Consequences of the Construction of a Wall in the Occupied Palestinian Territory, supra note 11, para. 41. 